\title{
PELAKSANAAN PELAYANAN PRIMA DI KANTOR DINAS KEPENDUDUKAN DAN CATATAN SIPIL KABUPATEN KEDIRI
}

\author{
*Teguh Pramono ${ }^{1)}$, Djoko Susanto ${ }^{2)}$, Elly Widiarti ${ }^{3)}$ \\ 1)Prodi Studi Administrasi Publik, Universitas Kadiri, Indonesia \\ 2) Prodi Studi Administrasi Publik, Universitas Kadiri, Indonesia \\ 3) Prodi Studi Administrasi Publik, Universitas Kadiri, Indonesia \\ *Email Korespondensi : widiartielly@gmail.com
}

\begin{abstract}
Abstrak
Penelitian ini bertujuan untuk mendeskripsikan dan menganalisis pelaksanaan pelayanan prima di Kantor Dinas Kependudukan dan Catatan Sipil Kabupaten Kediri, serta mendeskripsikan dan menganalisis faktor yang mendukung atau menghambat pelaksanaan pelayanan prima di Kantor Dinas Kependudukan dan Catatan Sipil Kabupaten Kediri. Fokus dalam penelitian ini meliputi sikap (attitude), kemampuan (ability), perhatian (attention), tindakan (action), tanggung jawab (accountability), dan penampilan (appearance). Pendekatan yang digunakan dalam penelitian ini adalah pendekatan kualitatif. Teknik pengumpulan data dalam penelitian ini meliputi wawancara dan observasi yang ditulis dalam catatan lapangan. Keabsahan data dikaji dengan 2 metode yakni trianggulasi dan ketekunan pengamatan. Sementara itu, teknik analisis data mengacu pada Miles dan Huberman (2018). Kesimpulan yang dapat ditarik yaitu pelaksanaan pelayanan prima di Kantor Dinas Kependudukan dan Catatan Sipil Kabupaten Kediri belum sepenuhnya 100\% baik, masih ada beberapa yang perlu diperbaiki dan dievaluasi. Hambatan yang ditemui adalah sumber daya manusia yang tidak sebanding dengan pemohon dan sarana dan prasarana.
\end{abstract}

Kata Kunci: Pelayanan Prima, Disdukcapil, Hambatan, Sikap, Penampilan

\begin{abstract}
This study aims to describe and analyze the implementation of excellent service at the Kediri Regency Population and Civil Registry Office, as well as describe and analyze the factors that support or hinder the implementation of excellent service at the Kediri Regency Population and Civil Registry Office. The focus in this study includes attitude, ability, attention, action, accountability, and appearance. The approach used in this study is qualitative. Data collection techniques in this study include interviews and observations written in field notes. The validity of the data was assessed by 2 methods, namely triangulation, and persistence of observation. Meanwhile, the data analysis technique refers to Miles and Huberman (2018). The conclusion that can be drawn is that the implementation of excellent service at the Kediri Regency Population and Civil Registry Office is not yet 100\% good, there are still some that need to be improved and
\end{abstract}


evaluated. The obstacles encountered are human resources that are not comparable to the applicant and facilities and infrastructure.

Keywords: Excellent Service, Department of Population and Civil Registry, Barriers, Attitudes, Appearance.

\section{PENDAHULUAN}

Pelayanan pada dasarnya suautu rangkaian aktivitas, serta berlangsung secara teratur serta berkesinambungan, meliputi segala kehidupan organisasi di dalam warga $(\mathrm{N}$. Hisbani, 2015). Secara universal yang diartikan dengan pelayanan merupakan aktivitas yang ditujukkan untuk memberikan pelayanan kepada pelanggan, dengan demikian kebutuhan pelanggan bisa terpenuhi (Ibrahim, 2019). Penafsiran pelayanan di dalam Kamus Besar Bahasa Indonesia, pelayanan merupakan usaha melayani kebutuhan warga. Sebaliknya, melayani merupakan menolong mempersiapkan apa yang dibutuhkan seseorang. Pelayanan merupakan pendekatan yang lengkap pula menciptakan mutu pelayanan untuk warga. Pengertian yang lain, pelayanan ialah tonggak utama untuk operasional di aktivitas bisnis serta ini memegang peranan yang sangat berarti. Bagi (S. Saggaf, 2014) di dalam novel yang bertajuk Moenir, berkomentar bahwa pelayanan merupakan proses pemenuhan kebutuhan yang didapat dari kegiatan orang lain buat penuhi kebutuhan pelanggan. Sedangkan pelayanan publik adalah aktivitas yang dilaksanakan oleh pemerintah terhadap manusia dengan tujuan buat penuhi keperluan hidup manusia ataupun yang mempunyai kepentingan dengan organisasi yang bersangkutan cocok dengan peraturan perundang-undangan yang berlaku (Dwiyanto, 2018). Penafsiran pelayanan bagi Loina (Taufan, 2020) di dalam bukunya menerangkan "pelayanan yakni proses totalitas suatu pembuatan citra dari industri, baik dengan lewat media kabar membentuk suatu budaya industri secara internal, maupun melaksanakan suatu komunikasi menimpa pemikiran industri pada para pemimpin pemerintahan dan publik yang yang lain yang berkepentingan". Pelayanan publik pula tercantum problematika yang lumayan menarik buat di analisis, sebab pelayanan publik bukan cuma buat meningkatkan intelegensi sesuatu kesempurnaan dalam pembangunan namun pula memandang sepanjang mana pertumbuhan pelayanannya dalam penyelenggaraan tugas dari bermacam bidang lembaga pada suatu kantor pemerintah. Bagi (N. Hisbani, 2015) 
pelayanan merupakan proses dorongan kepada orang lain dengan metode tertentu yang memerlukan kepekaan serta ikatan antar personal dengan tujuan buat menghasilkan sesuatu kepuasan serta keberhasilan. Akhirnya merupakan pelayanan ialah wujud aktivitas yang dilaksanakan di pemerintah pusat ataupun di wilayah ataupun di lembaga swasta. Pelayanan pula jadi aspek berarti dalam sesuatu organisasi, baik organisasi yang berorientasi profit ataupun organisasi publik, sebab pada dasarnya penerapan pelayanan pula berkaitan dengan upaya pencapaian tujuan ataupun misi organisasi secara maksimal. Tujuan berarti menimpa diperlukannya pelayanan merupakan supaya terwujudnya pelayanan yang efektif, efisien, serta murah cocok dengan kepentingan warga. Kebijakan memperkenalkan pelayanan publik yang lebih bermutu semacam Undang-Undang No 25 Tahun 2009 tentang Pelayanan Publik bersumber pada atas realitas kalau sebetulnya pelayanan publik pada dikala itu masih dihadapkan dengan keadaan yang belum cocok dengan kebutuhan serta pergantian di bermacam bidang. Pemicu pelayanan publik kurang baik/ tidak baik diakui sebab ketidaksiapan pemerintah buat menanggap terbentuknya transformasi nilai yang berukuran luas dan berakibat pada pembangunan yang lingkungan. Sedangkan itu, tatanan baru warga Indonesia dihadapkan pada harapan serta tantangan global yang dipicu oleh kemajuan di bidang ilmu pengetahuan, data, komunikasi serta perdagangan. Di dalam peraturan perundang- undangan tadinya pula mengendalikan tentang pelayanan publik yang dinilai tidak sanggup mengganti keadaan kurang baik pelayanan publik.

Pada proses pelayanan publik terdapat hubungan interaksi antara 2 faktor yaitu pihak Pemerintah dengan publik ataupun diketahui pula dengan istilah public service, yang dimana pemerintah selaku fasilitas serta publik selaku peminta pelayanan. Di dalam interaksi suatu pelayanan publik, sebaiknya birokrasi pemerintah selaku acuan yang berwibawa buat melayani kepentingan publik serta tidak dipersulit, namun menolong menghasilkan keadaan yang kondusif supaya bisa bawa pelayanan yang lebih efisien serta efektif. Pelayanan universal merupakan proses aktivitas yang dicoba oleh orang ataupun lembaga buat melayani serta sediakan kebutuhan benda serta jasa pelanggan sehingga tercapainya rasa puas untuk pelanggan. Perihal ini teruji kalau pemerintah lebih banyak membagikan kedudukan serta tanggung jawab kepada swasta ataupun kepada warga yang 
memerlukan pelayanan di bidang administrasi. Pelayanan politik yang sudah dilaksanakan oleh pemerintah telah menyangkut banyak bidang semacam kesehatan, kesejahteraan sosial, pembelajaran, pelayanan perijinan, serta lain-lain. Kedudukan pemerintah dalam penyediaan pelayanan publik sangat berarti, sebab permintaan pelayanan publik terus bertambah baik segi mutu ataupun kuantitasnya. Pelayanan publik bukan cuma perkara administratif saja namun lebih ke pemenuhan kemauan dari publik. Pelayanan publik merupakan pemberian pelayanan pemerintah kepada publik cocok dengan apa yang diharapkan dengan bayaran, waktu, serta kualitas yang diberikan relatif lebih baik (Rukayat, 2018). Di era modern, tidak hanya pelayanan publik pula terdapat pelayanan prima. Pelayanan prima merupakan pola pelayanan dalam manajemen modern yang mengutamakan kepedulian terhadap pelanggan/warga. Yang sangat berarti dalam membagikan pelayanan kepada pelanggan minimun memiliki kepedulian terhadap pelanggan, melayani pelanggan dengan baik serta memuaskan pelanggan dengan berorientasi pada standar layanan. Secara simpel pelayanan prima (excellent service) merupakan pelayanan yang penuhi standar mutu yang cocok dengan harapan serta kepuasan pelanggan. Dengan kata lain, pelayanan prima ialah sesuatu pelayanan yang penuhi standar mutu. Pelayanan prima ialah suatu kepedulian industri ataupun pemerintah terhadap pelanggan/warga dengan berupaya membagikan pelayanan sebaik bisa jadi dalam penuhi harapan (Semil, 2018). Pelayanan yang penuhi standar mutu merupakan pelayanan yang cocok dengan harapan serta kepuasaan pelanggan/warga. Kepuasaan ini bisa terwujud bila pelayanannya cocok dengan standar pelayanan yang telah diresmikan. Pelayanan prima memiliki khasiat buat tingkatkan mutu pelayanan serta jadi suatu acuan buat pengembangan penataan standar pelayanan baik di lembaga swasta ataupun pemerintah. Penduduk ialah sumber energi yang lumayan berarti dalam melakukan pelayanan di bermacam lembaga yang terdapat. Pada hakekatnya, pelayanan publik telah terdapat serta diatur dalam Undang-Undang No 25 Tahun 2009 tentang Pelayanan Publik serta Undang-Undang No 96 Tahun 2012 tentang Penerapan UU Nomor. 25 Tahun 2009 tentang Pelayanan Publik. Tujuan dibentuknya Undang-Undang tersebut merupakan unutk membagikan pelayanan kepada warga pula menolong di pelayanan administrasi ataupun di bidang yang lain (Ahdhan, 2017). Dengan demikian, pelayanan publik dikala 
ini butuh terdapatnya penigkatan pelayanan bersumber pada sebagian aspek, salah satunya merupakan attitude (perilaku). Aspek attitude (perilaku) ialah aspek yang berarti di dalam suatu pelayanan prima. Sebaliknya penafsiran pelayanan prima merupakan sesuatu aktivitas yang dicoba oleh seorang ataupun berkelompok yang memiliki tujuan buat membagikan rasa puas kepada warga dalam pelayananannya tersebut. Implementasi kebijakan pelayanan prima telah diresmikan bersumber pada Undang-Undang No 25 Tahun 2009.

\section{TINJAUAN PUSTAKA}

(Sofyan, 2013) dalam penelitiannya yang berjudul "Kinerja Pelayanan Kependudukan Pada Dinas Kependudukan dan Catatan Sipil Kabupaten Bandung Barat”. Hasil penelitian ini adalah "Kependudukan dan Catatan Sipil Kabupaten Bandung Barat berdasarkan pada 10 prinsip pelayanan yang ada, ternyata 5 dari 10 prinsip tersebut telah dapat dijalankan dengan baik, kelima prinsip dimaksud adalah mengenai Kesederhanaan Prosedur, Kejelasan, Keamanan, Tanggungjawab dan Kedisiplinan, Kesopanan dan Keramahan. Selanjutnya 5 (lima) prinsip dari 10 prinsip tersebut, ternyata dalam memberikan pelayanan pada dinas dimaksud, belum dapat terealisasi secara baik, sehingga masih perlu peningkatan kinerja pelayanan agar mencapai pada terciptanya pelayanan prima pada dinas tersebut. Kelima prinsip dimaksud adalah hal-hal yang berkaitan dengan Kepastian Waktu Pelayanan, Akurasi Produk Pelayanan, Kelengkapan Sarana dan Prasarana Pelayanan, Kemudahan Akses dan Kenyamanan dalam memberikan pelayanan".

Penelitian terdahulu yang dilakukan oleh (Dwimawanti, 2004)yang berjudul "Kualitas Pelayanan Publik (Salah Satu Parameter Keberhasilan Otonomi Daerah)“. Hasil penelitian ini adalah "Perubahan paradigma layanan dari birokrat yang berorientasi kepada masyarakat yang berorientasi juga diikuti dengan perubahan dalam budaya kerja, tercermin dalam perilaku dan perilaku yang berorientasi pada biaya. Oleh karena itu, layanan lebih murah, lebih baik dan lebih cepat bisa direalisasikan. Perubahan paradigma ini memaksa aparatur pemerintah untuk memberikan perhatian yang lebih besar terhadap berbagai dinamika aktual yang muncul di masyarakat. Masyarakat membutuhkan yang 
lebih baik dan lebih akurat layanan sejalan dengan perkembangan teknologi. Karena ini lambat, tidak efisien, dan prosedur birokrasi berorientasi pita merah harus ditinggalkan".

\section{METODE PENELITIAN}

Pendekatan yang digunakan pada penelitian ini adalah pendekatan deskriptif dimana dengan menggunakan analisa kualitatif. Penelitian deskripstif merupakan penelitian yang menyajikan data-data berdasarkan masalah yang diambil, atau menganalisis dan melakukan interprestasi yang bersifat komperatif atau korelatif untuk memecahkan masalah pada penelitian yang diambil.

Jenis yang digunakan pada penelitian ini adalah penelitian kualitatif, merupakan penelitian yang bersifat variabel tunggal tidak ada variabel pembanding. Dalam penelitian kualitatif dapat disimpulkan dalam penelitian kualitatif merupakan gagasan baru yang belum pernah ada. Gagasan baru ini dapat berupa deskripsi dari gambaran atau objek yang sebelumnya bersifat semua atau tidak ada kejelasannya hingga perlu adanya penelitian untuk menjadikan jelas keberadaannya.(Ibrahim, 2015).

Lokasi Penelitian ini ditetapkan di Kantor Dinas Kependudukan dan Catatan Sipil Kabupaten Kediri. Pemilihan lokasi penelitian ini didasarkan pada lokasi penelitian yang tidak terlalu jauh dan banyak pelayanan yang bisa diteliti dengan terjun langsung ke lapangan serta langsung mendapatkan data yang dibutuhkan.

Sumber data pada penelitian ini didapatkan dari orang, benda atau objek yang bersifat relevan dimana keterkaitan dengan masalah yang di teliti. Sumber pada penelitian ini berasal dari beberapa masyarakat yang berdomisili di Kabupaten Kediri, dengan informan penelitian terdiri dari 4 orang, yaitu : Kepala Seksi Bagian Umum dan Kepegawaian, Kepala Seksi Bagian Penyusunan Program, Ketua RT.20; dan serta masyarakat sebanyak 2 orang. Dengan dua jenis sumber data (Moleong, 2004) yaitu primer: data yang diperoleh dengan melakukan penelitian secara langsung dari responden yang diinginkan oleh peneliti dengan menggunakan teknik pengumpulan data dari hasil observasi dan wawancara/interview. Sedangkan data sekunder adalah data yang diperoleh 
secara tidak langsung dari objek yang diteliti antara lain bersumber dari sumber studi pustaka (library search) untuk mengumpulkan data-data melakui beberapa buku,peraturan-peraturan/undang-undang, maupun arsip/laporan.

Teknik analisa data yang di gunakan pada penelitian ini adalah menggunakan teori yang dikemukakan oleh (Miles, 2014) dalam buku yang telah direvisi mengemukakan bahwa Perbedaan data yang baru dengan yang lama adalah terletak pada, data reduction di ganti dengan condensation. Miles dan Huberman menuliskan Data Condensation refers to the process of selecting, focusing, simplifying, abstracting, and/or transforming the data that appear in the full corpus (body) of written up field notes, interview transkrip, documents, and other empirical materials. By condensing, we are making data stronger. (Rahardjo, 2011)

\section{HASIL DAN PEMBAHASAN}

Pelaksanaan pelayanan prima yang dilaksanakan di Kantor Dinas Kependudukan dan Catatan Sipil Kabupaten Kediri berdasarkan fokus penelitan yang tertulis yaitu sikap (attitude), kemampuan (ability), perhatian (attention), tindakan (action), tanggung jawab (accountability) dan penampilan (appearance) sudah terlaksana dengan baik. Tetapi, tidak semua faktor pelayanan prima berjalan dengan sempurna, karena masih ada beberapa yang belum terlaksana dengan baik. Hal itu disebabkan karena sumber daya manusia yang terbatas, tidak sesuai dengan jumlah masyarakat yang berdomisili di Kabupaten Kediri. Untuk hasil pelayanan prima pada bagian sikap (attitude), pegawai Dinas Kependudukan dan Catatan Sipil Kabupaten Kediri sudah baik. Hal itu disebabkan karena pegawai sudah melaksanakan tugas dan tanggung jawabnya sesuai dengan tugas pokok dan fungsi masing-masing. Selanjutnya perhatian (attention), bahwa pegawai Dinas Kependudukan dan Catatan Sipil Kabupaten Kediri sudah memberikan perhatiannya dengan baik kepada pemohon yang mengurus dokumen di Kantor Dinas Kependudukan dan Catatan Sipil. Pegawai Dinas Kependudukan dan Catatan Sipil Kabupaten Kediri dalam melaksanakan pelayanan sesuai dengan kemampuan (ability) sudah baik dan tidak ada kendala dalam melakukan tugas nya masing-masing. Karena 
semua pegawai sudah diberikan ilmu pengetahuan juga skill dalam menjalankan tugas pokok dan fungsinya. Tindakan (action) yang dilakukan oleh pegawai Dinas Kependudukan dan Catatan Sipil Kabupaten Kediri juga baik, hal itu disebabkan karena kecepatan dalam merespon pelayanan administrasi. Tetapi ada beberapa hal yang masih tidak sesuai dengan tindakan yang ada seperti trouble ketika pemohon sedang mengantri di loket pelayanan sehinggan perlu diberi penjelasan loket-loket sesuai dengan nama pelayanan yang dituju. Kemudian tanggung jawab (accountability) yang dilaksanakan oleh pegawai sudah baik dan sesuai dengan peraturan perundang-undangan yang berlaku. Penampilan (appearance) pegawai nya sudah baik. Hal itu terbukti dengan cara berpakaian nya yang seragam, menggunakan aksesoris yang tidak terlalu mencolok dan sudah memenuhi standart peraturan yang berlaku. Dan cara berkomunikasi pegawai terhadap masyarakat juga baik, menggunakan bahasa Indonesia dan bahasa Jawa.

\section{KESIMPULAN DAN SARAN}

Berdasarkan uraian dari hasil yang telah dijabarkan maka dapat disimpulkan bahwa Pelaksanaan Pelayanan Prima di Kantor Dinas Kependudukan dan Catatan Sipil Kabupaten Kediri sudah menjalankan tugas dan tanggung jawabnya dengan baik. Karena di setiap pelayanan administrasi tersebut belum sepenuhnya $100 \%$ berjalan dengan sempurna dan masih ada beberapa hambatan yang bisa diselesaikan dengan baik dengan cara evaluasi bersama. Dalam melayani masyarakat, pegawai Dinas Kependudukan dan Catatan Sipil Kabupaten Kediri dituntut untuk memberikan sikap yang baik kepada masyarakat karena dapat memberikan rasa yang nyaman bagi mereka yang membutuhkan pelayanan administrasi. Selanjutnya, kemampuan pegawai tersebut juga sudah baik. Pegawai juga sudah memberikan perhatian kepada pemohon dalam melayani mengurus dokumen yang diperlukan. Tindakan yang diberikan pegawai Dinas Kependudukan dan Catatan Sipil Kabupaten Kediri sudah baik, dan bertanggung jawab dengan baik sesuai dengan Undang-Undang yang berlaku. Penampilan pegawai Dinas Kependudukan dan Catatan Sipil Kabupaten Kediri dalam berpakaian seragam sudah baik dan sesuai dengan peraturan yang berlaku. 


\section{REFERENSI}

Ahdhan, R. D. 2017. Implementasi Undang-Undang Nomor 25 Tahun 2009 Tentang Pelayanan Publik Pada Dinas Kependudukan dan Pencatatan Sipil Kabupaten Paser. Jurnal Universitas Mulawarman, 2185-2199.

Dwimawanti, I. H. 2004. Kualitas Pelayanan Publik (Salah Satu Parameter Keberhasilan Otonomi Daerah).

Dwiyanto, A. 2018. Manajemen Pelayanan Publik: Peduli Inklusif Dan Kolaborasi.

Ibrahim, H. 2019. Teori dan Konsep Pelayanan Publik Serta Implementasinya.

Miles, M. B. 2014. Qualitative data analysis: A methods sourcebook. 3rd.

Moleong, L. J. 2004. Metodelogi penelitian. Bandung: Penerbit Remaja Rosdakarya,

N. Hisbani, M. K. 2015. Penerapan Inovasi Pelayanan Publik Di Dinas Kependudukan dan Catatan Sipil Kabupaten Enrekang. Kolaborasi: Jurnal Administrasi Publik,

Rahardjo, M. 2011. Metode pengumpulan data penelitian kualitatif.

Rukayat, Y. 2018. Kualitas pelayanan publik bidang administrasi kependudukan di kecamatan pasirjambu. Jurnal Ilmiah Magister Administrasi.

S. Saggaf, R. S. 2014. Pelayanan Fungsi Administrasi Perkantoran Modern. Jurnal Ad'ministrare, 20-27.

Semil, N. 2018. Pelayanan prima instansi pemerintah: kajian kritis pada sistem pelayanan publik di Indonesia. -: Prenada Media.

Sofyan, A. 2013. Kinerja Pelayanan Kependudukan Pada Dinas Kependudukan Dan Catatan Sipil Kabupaten Bandung Barat. Jurnal Uniyap, 141890.

Taufan, A. 2020. KEGIATAN PELAYANAN DI KANTOR KESYAHBANDARAN DAN OTORITAS PELABUHAN PELAYARAN KELAS II CILACAP. Karya Tulis. 